\title{
Semiotika Arsitektur Tradisional Sumbawa
}

\author{
Chairil Budiarto Amiuza, MSA \\ Jurusan Arsitektur Fakultas Teknik Universitas Brawijaya \\ amiuza@gmail.com
}

\begin{abstract}
ABSTRAK
Arsitektur rumah tradisional di Kabupaten Sumbawa masih memiliki korelasi antara rancangan tata susunan, tujuan-guna dan makna-arti terhadap masyarakat, lingkungan, dan budayanya yang unik, baik pada strata sosial atas maupun bawah. Identitas lokal dalam sebuah arsitektur yang tumbuh dalam masyarakat memiliki makna tersembunyi baik secara visual maupun non-visual. Sebagai artefak yang cukup kompleks dalam menggambarkan kebudayaan suatu kelompok masyarakat, arsitektur tradisional hadir dengan pesan-pesan tersurat maupun tersirat. Oleh karena itu perlu pendekatan sintaksis, pragmatis dan semantik dalam membaca pesan tersebut. Pendekatan kualitatif digunakan untuk menggali obyek-obyek arsitektural pada kawasan studi berdasarkan pandangan masyarakat setempat serta pemaknaannya juga mengikuti alur pemahaman setempat yang berkembang di sekitar kawasan studi. Penggambaran serta pengungkapan ciri visual pada elemen arsiektur yang terbentuk menguak makna tanda yang tersembunyi. Penerapan strata dan kodifikasi ciri visual dapat menggambarkan nilai budaya yang berkembang dalam masyarakat tentang keharmonisan antara manusia dan alam melalui lingkungan binaanya.
\end{abstract}

Kata kunci: identitas, sintaksis, pragmatis dan semantik

\begin{abstract}
The architecture of traditional houses in Sumbawa Regency still has a correlation between the layout design, the purpose-use and the meanings with the society, environment, and its unique culture, both in the upper and lower social strata. Local identity in an architecture that grows in society has a hidden meaning both visually and non-visually. As artifacts that are quite complex in describing the culture of a community group, traditional architecture comes with explicit or implicit messages. Therefore, it needs a syntactic, pragmatic and semantic approach in reading the message. A qualitative approach is used to explore architectural objects in the study area based on the views of the local community and their meanings also follow the local understanding path that develops around the study area. The visual representation and visual representation of the built-up elements revealed the hidden meaning of the sign. The application of strata and codification of visual traits can reflect the growing cultural values in society about the harmony between man and nature through his built environment.
\end{abstract}

Keywords: identity, syntac, pragmatism, semantic

\section{Pendahuluan}

Arsitektur tradisional Nusantara sangat beragam sesuai suku yang ada mulai dari Kepulauan yang paling barat di ujung pulau Sumatra sampai paling timur di pulau Papua terdapat beraneka ragam rumah tradisional dengan aneka corak dan ragamnya masing-masing. Ragam visual dalam rumah tradisional tersebut sudah barang tentu menjadi sarana komunikasi visual yang digunakan oleh masyarakat setempat. Arsitektur lebih dari sekedar sebuah perakitan bahan didirikan diatas sebidang lahan, akan tetapi merupakan sebuah manifestasi dari masalah yang beragam seperti budaya, sosial dan teknologi. Hal ini dikarenaakan Arsitektur juga merupakan sebuah solusi dari permasalahan iklim, budaya dan social yang ada dalam suatu masyaraakat. 
Arsitektur pada era kini menjadi bagian dari bahasa, khususnya bahasa visual yang memiliki unsur-unsur tersusun menjadi sebuah gramatika Arsitektur yang bisa dibaca dan mengungkapkan interelasi unsur-unsurnya serta memiliki tujuan dan fungsi tertentu yang mengandung makna dan arti tertentu pula. Seperti halnya rumah traditional Jawa yang telah banyak diulas dalam beberapa artikel, rumah tradisional Lombok juga memiliki aturan dan norma tertentu dalam membaangunnya.

Masyarakat tradisional aslinya memilik bahasa membangun rumah dan lingkungannya berdasarkan kepercayaan dan kesepakatan masyarakatnya, sehingga Arsitektur Lingkungan dan rumah tinggalnya memiliki tata cara membangun, tata susunan unsur unsur yang diperlukan, tidak saja sebatas fungsi perlindungan belaka, tetapi juga dilihat dari tujuan dan fungsi lingkungan dan Rumah tinggal sebagai wujud komunikasi sosial dan budaya, kesetimbangan ekosistem lingkungannya dan nilai nilai spiritual penghuni dan masyarakatnya. Disamping itu penggunan bahan, tata letak ruang, tatasusun konstrusi serta ragam hias yang menyertainya memiliki arti dan makna tertentu terkait dengan kepercayaan, ritual, strata sosial dan alam lingkungan.

Diantara berbagai pulau yang tersebar dikepulauan di Nusa tenggara terdapat sebuah pulau besar yang dikenal dengan pulau Sumbawa, meskipun pulau ini berdekatan dengan pulau Lombok dan pulau Bali yang sudah banyak dikenal budaya maupun Arsitekturnya, masih jarang oraang memperhatikan secara lebih cermat dan mendetail, terutama dari sudut pembacaan tanda visual atau semiotika arsitektur.

Pada dasarnya, Sumbawa merupakan sebuah pulau dimana tradisi dan kebudayaan masih sangat kental terlihat dan terpelihara hingga kini. Hal tersebut bahkan Nampak kita jumpai pada cara berhuni mereka. Akan tetapi, sangat disayangkan jika pergeseran mulai terlihat akhir-akhir ini dikarenakan semakin gencarnya intervensi budaya dari luar yang lebih mendominasi dan menjadi tren bagi remaja disana.

Jika ditilik dari keragaman rumah adat Sumbawa, akan kita jumpai beragam penampakan visual, baik dimensi, proporsi, peruntukan dan ragam hiasnya. Beberapa diantaranya yang dapat kita jumpai yaitu bangunan rumah adat dalam loka, rumah adat bale Pekat dan rumah adat bale Panggung. Sebagai aset kebudayaan Nusantara perlu kiranya keberadaan artefak arsitektur tersebut dikaji dan dilestarikan, karena sampai saat ini belum ada informasi yang jelas hanya sebatas observasi lapangan dan wawancara dengan pemangku adat. Nampaknya Rumah Adat tersebut penuh dengan makna, sehingga melalui bahasa visual aset tersebut di analisis berdasarkan aspekaspek semiotikanya.

Sebagai aset penting Arsitektur Nusantara yang perlu didokumentasikan agar bisa dijadikan pengembangan desain Arsitektur yang berciri lokalitas, Khususnya wujud tanda visual perlu adanya penelusuran konfigurasi dan interelasi unsur unsur visual, tujuan yang terkandung didalamya dan arti dan makna Arsitektur trasional Sumbawa tersebut.

Bagaimanakah konfigurasi dan interelasi unsur-unsur Visual Arsitektur Rumah Tradisional Sumbawa tersebut. Tujuan apakah yang diharapkan oleh pengguna dan tercapaikah tujuan tersebut bagi masyrakat pemakainya. Arti dan makna apakah yang direkatkan oleh pengguna dan sesuaikah bagi masyarakat pemakainya.

\section{Tinjauan Pustaka}

Semiotika Arsitektural telah menjadi issu populer di kalangan teoritikus Arsitektur sejak tahun 1970, bahkan muncul istilah baru yaitu "Arsisemiotik" 
(Archisemiotics). Semiotika Arsitektur dapat memperkaya hasanah desain yang menyangkut tata bentuk dan ruang arsitektur.

Berdasarkan semiotika, Arsitektur dapat dibaca sebagai teks atau bahasa yang memiliki tata bahasa sintak, semantik dan prakmatik (Agus, 2003), maka unsur unsur desain arsitektur dapat dibaca sebagai berikut:

- Dari segi Sintaksis, dapat dilihat unsur unsur arsitektur sebagai tanda tanda berupa bentuk dan ruang dan kerjasama antara tanda tanda tersebut.

- Dari segi Semantik, dapat dilihat unsur unsur arsitektur sebagai tanda tanda berupa bentuk dan ruang dengan denotatumnya yang memiliki pula konotatumnya.

- Dari segi prakmatik, dapat dilihat unsur unsur arsitektur sebagai tanda tanda berupa bentuk dan ruang memiliki arti bagi pemakainya.

Richards (dalam Broadbent, 1980), mengilustrasikan hubungan tersebut sebagai segitga semiotika. Menurut Richards dalam semiotika arsitektur terdapat hubungan antara pemberi tanda (signifier), pesan yang terkandung dalam tanda (signified) dan fungsi tanda bagi pemakainya. Penjelasan Semiotika, Arsitektur dan hubungannya dapat ditarik kesimpulan bahwa desain arsitektur apapun sebagai bahasa visual dapat ditelusuri atau dikaji lewat media bahasa tanda atau simbol yang terkadung didalamnya.

Sintaksis menegaskan pengetahuan tentang gabungan elemen elemen atau unsur unsur desain. Unsur desain yang mana yang dapat dikombinasakan?, bagaimana caranya? Untuk apa?(Zahnd, 2009). Pembentukan elemen arsitektur berkaitan dengan penataan yang juga mengikuti aturan pola yang ada dalam sintaksia arsitektur. Sintaks arsitektur melibatkan mofologi dari empat aspek secara langsung sebagai berikut:

- Sintaksis massa, memperhatikan kombinasi semua elemen arsitektur yang berkaitan dengan massa.

- Sintaksis ruang, memperhatikan kombinasi semua elemen arsitektur yang bersifat spasial atau berkaitan dengan ruang.

- Sintaksis fungsi, memperhatikan kombinasi semua elemen arsitektur ysng bersifat atau berkaitan dengan fungsi.

- Sintaksis konstruksi, memperhatikan kombinasi semua elemen arsitektur yang bersifat atau berkaitan dengan konstruksi.

Dalam bidang arsitektur perlu pula ditanyakan makna dalam arsitektur?, materi tersebut difokuskan di subbidang Semantik yang berfokus pada pengetahuan makna dan arti dalam satu elemen atau kelompok pembentukan (zahnd,2009). Empat pertanyaan penting berikut yang perlu dijawab secara arsitektural. Apa itu?, apa itu penting?, untuk apa? Bagaimana cara mencapainya?, keempat pertanyaan tersebut membahas empat aspek semantik dalam satu obyek.

- Referensi: Sebuah obyek arsitektur memiliki ciri ciri yang dapat dihubungkan dengan kode tertentu yang dikenal umum.

- Relevansi: Sebuah obyek arsitektur memiliki ciri ciri yang dapat dihubungkan dengan fungsi tertentu yang dikenal umum.

- Maksud: Sebuah obyek arsitektur memiliki ciri ciri yang dapat dihubungkan dengan maksud tertentu yang dikenal umum.

- Ekspresi: Sebuah obyek arsitektur memiliki ciri ciri yang dapat dihubungkan dengan nilai tertentu yang dikenal umum.

Semantik arsitektur memiliki lima variabel sebagai berikut:Bentuk/Wujud; Ukuran/Skala; Bahan/Konstruksi; Letak/Posisi 
- Aspek prakmatik sering menjadi kriteria utama dalam realitas desain arsitektur. Kenyataan tersebut menentukan karya arsitektur bermanfaat atau tidak. (Zahnd, 2009).

- Aspek pragmatik arsitektur mencakup variabel sebagai berikut:Yang membangun; Penghuni/pemakai; Fungsi/guna; Waktu/lama dibangun; LokasiTeknik membangun;Teknik Bangunan; pihak yang terlibat; Sarana dan prasarana.

- Aspek prakmatik pada umumnya pada bangunan tradisional sangat menentukan sehingga hasil karya tersebut menjadikan karya yang baik dan detail.

\section{Metode Penelitian}

Penelitian ini menggunakan pendekatan kualitatif untuk menggali obyek-obyek visual dalam kawasan studi yang menurut pandangan masyarakat penduduk setempat memiliki tanda tanda atau simbol simbol tertentu bagi lingkungan. Tahap awal dilakukan observasi lapangan dan wawancara kepada masyarakat asli dan kunci. Hasil yang diperoleh dalam tahap ini digunakan sebagai acuan dasar untuk merekonstruksi konfigurasi visual dalam skala rumah tinggal, selubung luar bangunan dan ruang dalam serta detail ragam hias yang ada di rumah tinggal tersebut.

Tahap selanjutnya, merekonstruksi konfigurasi visual dalam skala rumah tinggal, selubung luar bangunan dan ruang dalam serta detail ragam hias yang ada di rumah tinggal tersebut. Hasil rekonstruksi visual tersebut sebagai bahan stimuli untuk menggali penilaian masyarakat terhadap obyek-obyek visual tersebut, yang dilakukan dengan pendekatan kualitatif pula, dan menggali kriteria evaluatif yang digunakan masyarakat dalam penilaian tersebut atau makna yang dilekatkan masyarakat terhadap obyek-obyek visual tersebut.

\section{Pembahasan}

\subsection{Sumbawa dalam kacamata Historis}

Berdasarkan informasi yang ada (Wikipedia, 2015) Kesultanan Sumbawa atau juga dikenal dengan Kerajaan Samawa ${ }^{[1]}$ adalah salah satu dari tiga kerajaan Islam besar di Pulau Sumbawa. Keberadaan Tana Samawa atau wilayah Sumbawa, mulai dicatat oleh sejarah sejak zaman Dinasti Dewa Awan Kuning, tetapi tidak banyak sumber tertulis yang bisa dijadikan bahan acuan untuk mengungkapkan situasi dan kondisi pada waktu itu. Sebagaimana masyarakat di daerah lain, sebagian rakyat Sumbawa masih menganut animisme dan sebagian sudah menganut agama Hindu. Baru pada kekuasaan raja terakhir dari Dinasti Awan Kuning, yaitu Dewa Maja Purwa, ditemukan catatan tentang kegiatan pemerintahan kerajaan, antara lain bahwa Dewa Maja Purwa telah menandatangani perjanjian dengan Kerajaan Gowa di Sulawesi. Perjanjian itu baru sebatas perdagangan antara kedua kerajaan kemudian ditingkatkan lagi dengan perjanjian saling menjaga keamanan dan ketertiban. Kerajaan Gowa yang pengaruhnya lebih besar saat itu menjadi pelindung Kerajaan Samawa.

Menurut Zolinger, agama Islam masuk ke Pulau Sumbawa lebih dahulu dari pada Pulau Lombok antara tahun 1450-1540 yang dibawa oleh para pedagang Islam dari Jawa dan Sumatera, khususnya Palembang. Selanjutnya runtuhnya Kerajaan Majapahit telah mengakibatkan kerajaan-kerajaan kecil di wilayah Sumbawa menjadi kerajaankerajaan yang merdeka. Kondisi ini justru memudahkan bagi proses pengenalan ajaran Islam oleh para mubaligh tersebut, kemudian pada tahun-tahun awal pada abad ke-16, 
Sunan Prapen yang merupakan keturunan Sunan Giri dari Jawa datang untuk menyebarkan Islam pada kerajaan-kerajaan Hindu di Sumbawa, dan terakhir penaklukan Karaeng Moroangang dari Kerajaan Gowa tahun 1618 atas Kerajaan Dewa Maja Paruwa (Utan) sebagai kerajaan terakhir yang bersedia masuk Islam sehingga menghasilkan sumpah: "Adat dan rapang Samawa (contoh-contoh kebaikan) tidak akan diganggu gugat sepanjang raja dan rakyatnya menjalankan syariat Islam".

\subsection{Seni Budaya masyarakat Sumbawa}

Suku Sumbawa adalah campuran kelompok etnik-etnik pendatang yang telah membaur dengan kelompok etnik pendatang yang lebih dahulu mendiami bekas wilayah Kesultanan Sumbawa, sehingga melahirkan kesadaran akan identitas budaya sendiri yang dicirikan dengan kehadiran bahasa Sumbawa atau basa Samawa sebagai bahasa persatuan antaretnik yang mendiami sebagian pulau ini.

Mahsun (2002) dalam Prospek Pemekaran Kabupaten Sumbawa mencatat bahwa sebelum bahasa Sumbawa purba (prabahasa Sumbawa) pecah ke dalam empat dialek yang ada sekarang ini, terlebih dahulu pecah ke dalam dua dialek, yaitu pradialek Taliwang-Jereweh-Tongo dan dialek Sumbawa besar atau cikal bakalnya disebut dialek Seran. Kemudian variasi ini berkembang seiring perjalanan waktu hingga memasuki fase historis, pradialek Taliwang-Jereweh-Tongo pecah lagi menjadi tiga dialek yang berdiri sendiri.

Pada kehidupan masyarakat Sumbawa tradisional, beberapa keluarga inti dapat tinggal dalam satu rumah panggung, yaitu rumah yang didirikan di atas tiang kayu yang tingginya berkisar antara 1,5 hingga 2 meter dengan tipologi persegi panjang, atapnya berbentuk seperti perahu yang terbuat dari santek atau bambu yang dipotong-potong (kini banyak diganti dengan genting). Pada bagian depan atau peladang dan bagian belakang dipasang anak tangga dalam hitungan ganjil antara 7, 9, 11 bergantung keperluannya. Adapun tata ruang bagian dalam umumnya merupakan perpaduan antara bentuk rumah adat Bugis-Makassar yang dikombinasi dengan arsitektur rumah orang Melayu.

Untuk rumah-rumah panggung di pedesaan lebih disukai menghadap ke timur atau matahari terbit yang melambangkan kekuatan, ketabahan, dan harapan limpahan rezeki. Masyarakat Sumbawa yang tinggal di desa-desa umumnya memiliki tempat khusus untuk menyimpan hasil penennya dalam sebuah klompo atau lumbung yang dibangun berdekatan dengan bangunan rumahnya, sedang bagi tau Samawa yang tidak menyimpan hasil panennya di lumbang, dapat pula memanfaatkan para atau loteng rumahnya, sedangkan untuk peralatan pertaninan ditempatkan di bongan atau kolong pada bagian bawah rumah panggungnya.

Arsitektur Samawa menggunakan struktur isatana dan sangat dipengaruhi oleh arsitektur Makasar, baik pada perumahan bangsawan, maupun perumahan rakyat biasa dan terdiri dari banyak variasi lokal. Peninggalan istana tua (dalam loka) mengacu pada mode Balla Lompoa di Goa. Karakteristiknya, bangunan berdiri diatas tiang kayu, dinding kayu, lantai kayu, atau kayu genting. Dinding, tangga dan bagian - bagian tertentu diukir dan ditonjolkan secara megah. Lingkungan alam selalu dikaitkan dengan sebuah elemen yang penting dan utama dalam arsitektur Samawa. Dalam memilih lokasi untuk bangunan, tau samawa cendrung mengikatkan makna khusus ada rinsirinsi pertahanan yang menguasai filosofi Samawa.

Gaya bangunan di Tana Samawa mulai dari bangunan rumah, balai desa, mesjid, langgar, mushallah, lumbung dsb, selalu mengacu pada arsitektur tradisional dengan 
empat persegi panjang dan model atau seperti perahu. Bahkan, walaupun saat ini arsitektur moderen sudah memasuki dan kuat pengaruhinya pada arsitektur Samawa, filosofi dasarnya tetap saja dipertahankan. Kecuali ada penataan ruang, lantai dan ornamen lainya.

Di tana Samawa dikenal banyak jenis upacara adat, mulai dari upacara adat daur hidup/ life cycle, seperti proses kelahiran, masa kanak - kanak, masa remaja dan perkawinan sampai pada upacara kematian disamping upacara yang berkaitan dengan memulai suatu pekerjaan seperti bangun rumah. Melakukan kenduri (basadekah) juga menjadi bagian penting dari adat Samawa, seperti : sadekah orong, sadekah rapina bale, sadekah tolak bala, belo umir, sadekah yang berhubungan dengan perkawinan, sunat rasul, kelahiran nabi (munit) dsb.Dalam pelaksanaan upacara - upacara tersebut biasanya digelar kesenian daerah seperi : ratib, bagenang, langko, saketa, sakeco, lawas, dll. Dikenal tiga sistem gotong royong dalam masyarakat samawa yaitu Saling tulong (tolong menolong) basiru (saling tolong menolong untuk pekerjaan yang ditujukan hasilnya untuk seseorang) dan ketiga adalang nulong (membantu).

Baik saling tulong, basiru, maupun nulong biasanya tidak hanya dalam bentuk materian tapi juga tenaga. Saling tulong bisa diartikan sebagai pemberian pertolongan yang akan dibalas pada kesempatan lain.Basiru, lebih pada pengertian mengajak beramai - ramai mengerjakan sesuatu pekerjaan yang nantinya juga beramai - ramai mengerjakan pekerjaan dari yang lainnya. Nulong lebih dikhususnya pada adanya imbalan berupa jasa atau materi.

\subsection{Rumah Tinggal Tradisional Sumbawa}

Geografis, historis dan Seni budaya yang melingkupi masyarakat Sumbawa, mewujudkan tempat- tempat hunian berupa Rumah Tinggal yang secara arsitektural sangat beragam, mulai dari yang Tradisonal, Kolonial dan Modern sampai yang hibrida.

Khususnya Rumah Tinggal Tradisional Sumbawa sudah jarang ditemui secara

utuh dan masih dihuni atau dibangun kembali dengan cara masyarakat tradisi Sumbawa. Namun demikian masih ada yang representatif untuk mewakili sampel studi Rumah Tradisional Sumbawa dari sudut pandang bahasa visual atau Semiotika.

Masyarakat Sumbawa secara tadisional terbagi dalam tiga strata sosial, yaitu keluarga kerajaan, pembesar kerajaan dan masyarakat biasa. Mereka masih ada meskipun sudah membaur dalam masyarakat umum. Rumah tinggal mereka semula berada dan terbangun dalam wujud yang menunjukan strara tersebut, bila dilihat secara visualnya. Rumah tinggal Tradisi mereka memiliki nama yang khusus bagi masyarakat Sumbawa, yaitu Dalam Loka, Bale Pekat dan bale Panggung.

Dalam Loka adalah Rumah tinggal keluarga kerajaan atau istana, Bale pekat adalah rumah tinggal keluarga pembesar kerajaan sedangkan Bale Panggung adalah rumah tinggal rakyat umumnya. Rumah Tinggal Tradisional Sumbawa yang representatif untuk mewakili sampel studi Rumah Tradisional Sumbawa dari sudut pandang bahasa visual atau Semiotika diambil masing masing satu sampel berhubung tersedianya sampel tersebut terbatas, satu buah Bangunan Dalam loka, satu buah bangunan Bale pekat dan satu buah bangunan Bale Panggung. 


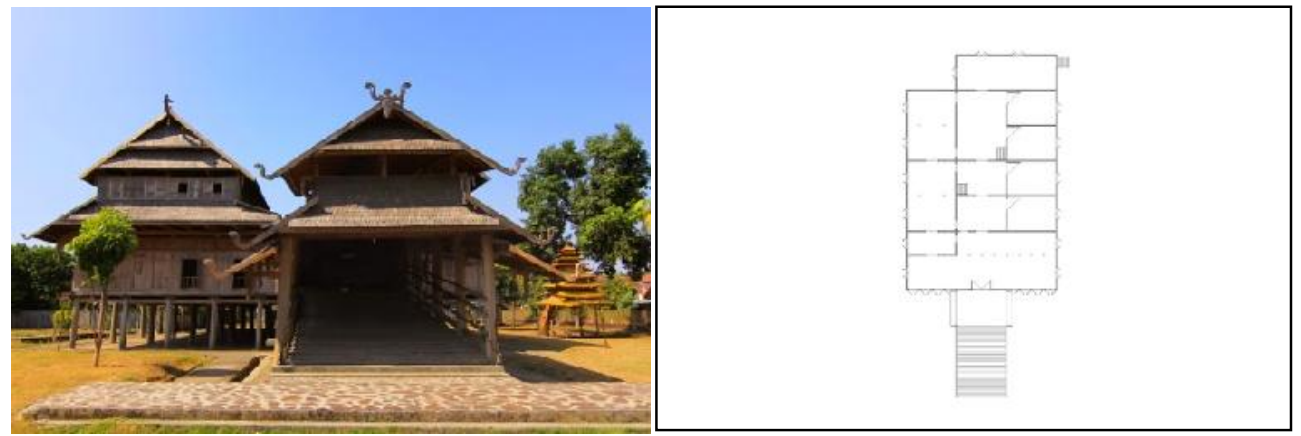

Gambar 1. Dalam loka (tampak depan dan denah)

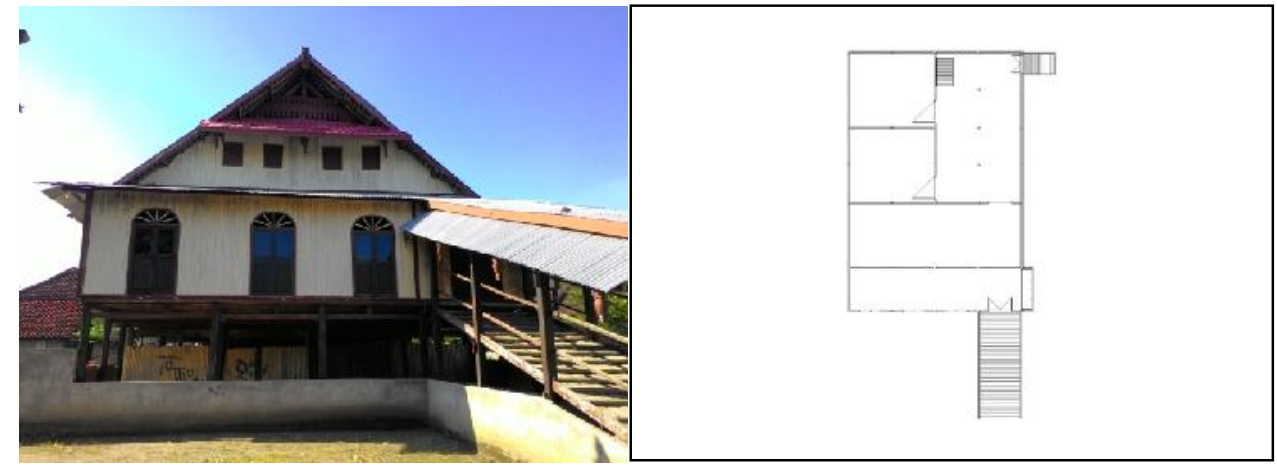

Gambar 2. Denah Bale Pekat (tampak dan denah)

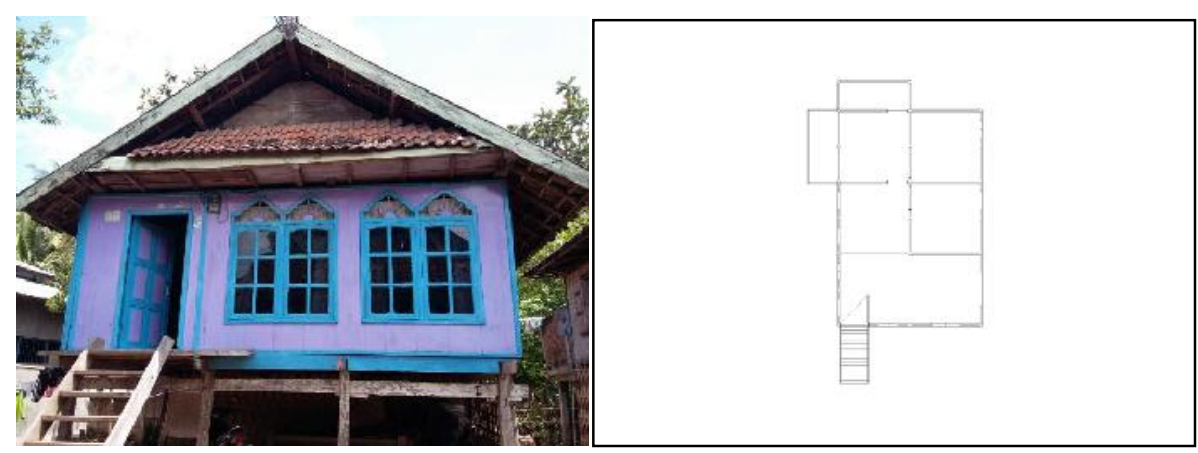

Gambar 3. Bale Panggung (tampak dan denah)

Tabel 1. Analisis Sintaksis

\begin{tabular}{cll}
\hline No & $\begin{array}{l}\text { Arsitektur } \\
\text { tradisional }\end{array}$ & \multicolumn{1}{c}{ Penjelasan Sintaksis } \\
\hline $\mathbf{1}$ & $\begin{array}{l}\text { Dalam } \\
\text { Loka }\end{array}$ & $\begin{array}{l}\text { terdiri dari tiga masa termasuk massa tangga. 2 Massa utama berbentuk balok } \\
\text { memanjang dan bersusun dengan bentuk yang setangkup. Ruang ruang tersusun } \\
\text { secara hirarhi paralel dan vertikal ( 2 lantai). Zonasi ruang terbagi tiga bagian, zona } \\
\text { publik (tempat raja menjalankan pemerintahan), zona privat (tempat keluarga raja } \\
\text { berdiam), dan zona semi privat (tempat pelayanan kegiatan pemerintahan dan } \\
\text { hunian). Fungsi kegiatan pemerintahan adalah pada massa sisi kanan sedangkan } \\
\text { fungsi hunian pada massa sisi kiri. Konstruksi bangunan keseluruhan menggunakan } \\
\text { konstruksi kayu dengan sistim sambungan sumbu-pasak dengan kerangka apit } \\
\end{array}$ \\
& udang pada atap. Kolom-kolom kayu berdiri diatas umpak batu gunung.
\end{tabular}


2 Bale Pekat terdiri dari dua masa termasuk massa tangga. 2 Massa utama berbentuk balok memanjang. Ruang ruang tersusun secara khirarhi linier dan vertikal ( 2 lantai). Sonasi ruang terbagi tiga bagian, zona ruang publik, tempat bangsawan menerima masyarakat, zona privat, tempat keluarga bangsawan berdiam dan zona semi privat tempat pelayanan kegiatan pemerintahan dan hunian. Fungsi kegiatan pemerintahan pada ruang depan sedangkan fungsi hunian pada ruang tengah dan pelayanan pada ruang belakang. Konstruksi bangunan keseluruhan menggunakan konstruksi kayu dengan sistim sambungan sumbu-pasak dengan kerangka apit udang pada atap. Kolom-kolom kayu berdiri diatas umpak batu gunung

3 Bale terdiri dari satu masa dengan tangga terbuka. Massa utama berbentuk balok Panggung memanjang. Ruang ruang tersusun secara khirarhi linier. Sonasi ruang terbagi tiga bagian, zona ruang publik, tempat penghuni menerima tamu, zona privat, tempat keluarga berdiam dan zona semi privat tempat pelayanan kegiatan hunian. Fungsi kegiatan publik pada ruang depan sedangkan fungsi hunian pada ruang tengah dan pelayanan pada ruang belakang. Konstruksi bangunan keseluruhan menggunakan konstruksi kayu dengan sistim sambungan sumbu-pasak dengan kerangka apit udang pada atap. Kolom-kolom kayu berdiri diatas umpak batu gunung

Tabel 2. Analisis Pragmatik

\begin{tabular}{|c|c|c|}
\hline No & $\begin{array}{l}\text { Arsitektur } \\
\text { tradisional }\end{array}$ & Penjelasan Pragmatis \\
\hline 1 & $\begin{array}{l}\text { Dalam } \\
\text { Loka }\end{array}$ & $\begin{array}{l}\text { Dalam loka, yang membangun adalah ketua adat dibantu para tenaga ahli dan } \\
\text { masyarakat. Pembangunan bertujuan untuk pusat pemerintahan sekaligus hunian } \\
\text { raja. Dalam Loka dibangun pada abad } 18 \text { di pusat Kota Kerajaan. Pembangunan } \\
\text { dilakukan secara analogik, mengibaratkan bangunan sebagai bentuk perahu besar } \\
\text { dengan detail yang lengkap dengan dek, tangga, anjungan dan buritan. Tidak ada } \\
\text { informasi yang jelas berapa lama waktu pembangunannya, tetapi pada abad ke 18, } \\
\text { bangunan ini telah berdiri. Ditinjau dari fisiknya, bangunan ini dibangun secara } \\
\text { manual dengan keahlian menonjol dari pertukangan kayu. Kayu yang digunakan } \\
\text { berukuran cukup besar, dan digunakan sebagai konstruksi panggung, dinding, lantai } \\
\text { dan atap. Bangunan istana ini memiliki detail dan ornamentasi yang khas }\end{array}$ \\
\hline 2 & Bale Pekat & $\begin{array}{l}\text { Bale Pekat, dibangun oleh ketua adat dibantu masyarakat adat Sumbawa. Fungsi } \\
\text { bangunan adalah sebagai hunian bangsawan dan para pembantunya. Bale Pekat } \\
\text { dirancang sebagai puri dan dibangun sesudah abad } 18 \text { di pinggiran Kota Kerajaan. } \\
\text { Metode membangunannya menggunakan cara ikonik, mengikuti kebiasaan } \\
\text { membangunan masyarakat pendatang (Bugis) strata bangsawan. Bangunan ini } \\
\text { berdiri pada abad ke 19. Pembangunan, dilakukan secara manual dengan keahlian } \\
\text { berbagai bidang bangunan khususnya kayu. }\end{array}$ \\
\hline 3 & $\begin{array}{l}\text { Bale } \\
\text { Panggung }\end{array}$ & $\begin{array}{l}\text { Bale panggung didirikan oleh masyarakat adat Sumbawa secara gotong royong, dan } \\
\text { digunakan untuk tempat tinggal rakyat. Bale panggung dibangun pada sesudah abad } \\
19 \text { di perkampungan adat. Pembangunan ddilakuan secara cara ikonik, yaitu } \\
\text { mengikuti kebiasaan membangun masyarakat pendatang (Bugis) berstrata sosial } \\
\text { rakyat. Pembangunannya memakan waktu tidak jelas informasinya, yang jelas sudah } \\
\text { berdiri pada abad ke 20. Pelaksanaan pembangunannya, bila dilihat dari phisik } \\
\text { bangunan dibangunan secara manual dengan kekhlian umum bidang bangunan } \\
\text { khususnya Material kayu setempat. Mereka membutuhkan material kayu yang cukup } \\
\text { mulai dari konstruksi panggung, dinding, lantai dan atap. }\end{array}$ \\
\hline
\end{tabular}


Tabel 3. Analisis Semantik

\begin{tabular}{|c|c|c|}
\hline No & $\begin{array}{l}\text { Arsitektur } \\
\text { tradisional }\end{array}$ & Penjelasan Semantik \\
\hline 1 & $\begin{array}{l}\text { Dalam } \\
\text { Loka }\end{array}$ & $\begin{array}{l}\text { Dalam Loka, bentuknya memiliki kode yang dikenal masyarakat sebagai bentuk yang } \\
\text { sakral dan berwibawa. Nilai tersebut ditunjukkan oleh ukuran yang giganti-besar } \\
\text { dengan skala monumental, didukung pola massa dan ruang setangkup dengan akses } \\
\text { tangga ditengah (sentral), dan bukaan yang rendah (dimaksudkan sebagai } \\
\text { penghormatan pada raja atau keluarganya). Konstruksi utama dari kayu yang di lapis } \\
\text { pengawet atau pulitur dengan ornamen tertentu sebagai bangunan istana yang } \\
\text { diletakkan di pusat kota di daerah perbukitan. Bentuk atap bersusun dengan tangga } \\
\text { beratap susun. Ornamennya menonjol dengan skala megah, pola susunan simetri, } \\
\text { sentral dan vertikal, bahan konstruksinya kayu-kayu besar, dan letaknya di } \\
\text { ketinggian menunjukkan hirakhi Dalam Loka yang setingkat di bawah masjid (masjid } \\
\text { sebagai hirarki tertinggi). Ciri-ciri bentuk/wujud, ukuran/skala, pola/susunan, } \\
\text { bahan/konstruksi serta letak/posisi Dalam loka dimaksudkan untuk menunjukkan } \\
\text { bangunan istana raja atau sultan dan mengekspresikan kebesaran dan kewibawaan }\end{array}$ \\
\hline 2 & Bale Pekat & $\begin{array}{l}\text { Bale Pekat, bentuknya memiliki kode yang dikenal masyarakat sebagai bentuk yang } \\
\text { berwibawa. Hal ini ditunjukkan oleh ukuran yang besar dan megah, serta didukung } \\
\text { pola massa dan ruang setangkup dengan akses tangga disisi kanan, dan bukaan yang } \\
\text { rendah (dimaksudkan sebagai penghormatan pada bangsawan atau keluarganya). } \\
\text { Konstruksi utama dari kayu yang dilapis pengawet kayu atau pulitur dengan } \\
\text { ornamen geometri sederhana. Bangunan ini berfungsi sebagai puri yang berada di } \\
\text { lembah pinggiran kota. }\end{array}$ \\
\hline 3 & $\begin{array}{l}\text { Bale } \\
\text { Panggung }\end{array}$ & $\begin{array}{l}\text { Bentuk atap tunggal dengan tangga beratap dengan ornamen yang menonjol dengan } \\
\text { skala wajar, pola susunan asimetri, dan vertikal, bahan konstruksi kayu dan letak } \\
\text { berada di lembah menunjukkan hirakhi Bale Pekat dibawah Dalam loka. Ciri-ciri } \\
\text { bentuk/wujud, ukuran/skala, pola/susunan, bahan/ konstruksi serta letak/posisi } \\
\text { keberadaan Bale Pekat dimaksudkan untuk menunjukkan bangunan Puri untuk } \\
\text { bangsawan kerajaan dan mengekspresikan pengayoman dan pelayanan }\end{array}$ \\
\hline
\end{tabular}

Kombinasi semua elemen arsitektur yang berkaitan dengan massa pada ketiga strata Rumah Tinggal tradisional Sumbawa berbeda secara bertingkat, Bangunan Dalam Loka terdiri dari 3 massa, bangunan Bale pekat terdiri dari 2 massa dan bangunan Bale Panggung terdiri dari 1 massa.

Kombinasi semua elemen arsitektur yang berhubungan dengan ruang pada ketiga strata Rumah Tinggal Tradisional Sumbawa berbeda secara hirakhi, Bangunan Dalam Loka susunan ruang secara paralel memusat, bangunan Bale Pekat susunan ruang secara paralel dan bangunan Bale Panggung susunan ruang secara linier.

Kombinasi semua elemen arsitektur yang berhubungan dengan fungsi pada ketiga strata Rumah Tinggal Tradisional Sumbawa juga berbeda, Bangunan Dalam Loka berfungsi pemerintahan dan kediaman, bangunan Bale pekat berfungsi sebagai pelayanan dan kediaman sedangkan Bangunan Bale Panggung berfungsi hanya sebagai kediaman.

Kombinasi semua elemen arsitektur yang berhubungan dengan konstruksi pada ketiga strata Rumah tinggal Tradisional Sumbawa memiliki kesamaan yaitu konstruksi panggung dengan sistim sambungan pasak hanya berbeda tingkat kompleksitas sambungan kayunya. Konstruksi bangunan panggung Dalam Loka multi komplek, Konstruksi bangunan panggung Bale pekat komplek sedangkan Konstruksi bangunan panggung Bale Panggung sederhana.

Aspek pelaksanaan penerapan rancangan Arsitektur dan kegunaan dari ketiga strata bangunan Rumah Tinggal Tradisional Sumbawa secara teknik bangunan dan teknik membangunnya sama, yaitu manual, gotong-royong dan konstruksi kayu, sedangkan dari aspek kefungsian berbeda dalam kapsitas material pekerjaannya. 
Bangunan Dalam Loka memerlukan jasa tenaga ahli yang cukup banyak melihat kebutuhan dan ketentuan sebagai pemerintahan dan kediaman raja, khususnya yang berkaitan dengan rancangan ragam hias sebagai simbol-simbol pada tempat tertentu. Bangunan Bale Pekat hanya menggunakan tenaga ahli yang ada di mayarakat. Bale Panggung dibangun oleh penghuni/pemiliknya dibantu oleh masyarakat setempat.

\section{Simpulan}

Berdasarkan pengamatan tanda visual Rumah Tinggal Tradisional Sumbawa, ketiga strata memiliki ciri-ciri yang dapat dihubungkan dengan kode, hirarki, fungsi dan nilai yang berbeda sesuai wujud tanda visual arsitekturalnya. Dalam Loka, dengan kode bentuk bersusun secara simetri, tangga beratap ditengah sebagai tempat yang formal dan agung, hiraki berjenjang secara horisontal dan vertikal berfungsi sebagai tempat pemerintahan. Fungsi pemerintahan tertinggi ini berada di lokasi yang tinggi dan di pusat kota. Bangunan ini memiliki nilai kewibawaan bagi masyrakatnya.

Bangunan Bale Pekat yang memiliki kode bentuk asimetri, tangga beratap di sisi kanan sebagai ruang semi formal dan terbuka, dan hirarki ruang berjenjang secara horisontal, digunakan sebagai tempat pelayanan masyarakat. Fungsinya adalah sebagai pembantu pemerintahan. Letaknya di antara pusat pemerintahan dan permukiman masyarakat. Bangunan ini memiliki nilai keterbukaan bagi masyarakatnya.

Bangunan Bale Panggung memiliki kode bentuk asimetri dengan tangga terbuka dan sederhana disisi kiri, hirarkinya berjenjang secara horisonal, dan digunakan sebagai tempat tinggal. Letaknya di perkampungan. Bangunan ini memiliki nilai kesederhanaan dan keakraban dengan lingkungan alam dan sosial masyarakatnya.

\section{Daftar Pustaka}

Atmadjaja. Srisusana. Jolanda. 2003. Estetika bentuk sebagai pendekatan Semiotika pada penelitian Arsitektur. Jurnal Desain \& Konstruksi 2(2)

Broadbent, G. 1980). Design in Architecture: Architecture and the Human Science. John Wiley \& Sons.

Dharma, A. Semiotika dalam Arsitek-tur http // staffsite.gunadarma. ac.id /agus dh/

Preziosi, D. 1979. The Semiotics of the Built Environment. London: Indiana University Press

Rapoport, A. 1982. The Meaning of the Built Environment. London: Sage Publications, Inc. Sachari, A. 2005. Pengantar Metodologi Penelitian Budaya Rupa. Jakarta: Erlangga.

Zahnd, M. 2009. Pendekatan dalam Perancangan Arsitektur. Semarang: Kanisius, Soegiapranata University Press 